\title{
Gonadotrophic, prolactin, corticosterone, and gonadal hormones levels over 15 months in Giant Amazon River Turtles - Podocnemis expansa (Schweigger, 1812) (Testudines: Podocnemididae), in captive conditions
}

\author{
G. E. Freneau ${ }^{*}$, V. A. Sáb C. R. Franci ${ }^{c}$, D. Vieira ${ }^{a}$ and B. N. Freneau ${ }^{a}$ \\ ${ }^{a}$ Laboratório de Andrologia e Tecnologia do Sêmen, Escola de Veterinária e Zootecnia, Universidade Federal \\ de Goiás - UFG, Campus I UFG, CP 131, CEP 74001-970, Goiânia, GO, Brazil \\ 'Divisão Fiscalização de Material Genético Animal, Ministério da Agricultura, Pecuária e Abastecimento, \\ Esplanada dos Ministérios, Bloco D, CEP 70043-900, Brasília, DF, Brazil \\ 'Departamento de Fisiologia, Faculdade de Medicina de Ribeirão Preto, Universidade de São Paulo - USP, \\ Av. Bandeirantes, 3900, Monte Alegre, CEP 14049-900, Ribeirão Preto, SP, Brazil \\ *e-mail: gfreneau@ufg.br, gfreneau@gmail.com
}

Received: March 20, 2015 - Accepted: August 20, 2015 - Distributed: November 30, 2016

(With 1 figure)

\begin{abstract}
In order to achieve successful captive breeding the Podocnemis expansa, it is necessary to study their reproductive endocrinology. The purpose of this research was to evaluate and characterize plasma concentrations in gonadotrophic, gonadic, corticosterone and prolactin hormones from Giant Amazon Turtles under captive conditions. Blood samples were collected over a 15 month period. The samples were assayed by the use of radioimmunoassay, prolactin, corticosterone, $\mathrm{LH}, \mathrm{FSH}$, testosterone, $17 \beta$-estradiol and progesterone. We verified significant seasonal pattern increase in $17 \beta$-estradiol levels and decrease in progesterone levels in the course of a year, which indicates vitellogenesis. This is related to normal ovarian cycles and possibly to the functional integrity of the hypothalamus-pituitary-gonad axis of captive females. There were negative correlations between testosterone and corticosterone in the male samples, suggestive of stress (management stress) on the reproductive system. The plasma concentrations of gonadotrophic, gonadic, prolactin and corticosterone hormones may be used as a reference for further research and possible therapeutic approaches. The data collected during this research are unprecedented for this species and may serve as a reference for future research regarding the reproductive cycle of this turtle, also allowing reproductive management while in captivity. Information about these hormones must be gathered from wild populations during different periods of the year for better clarification of the reproductive physiology of this species.
\end{abstract}

Keywords: Podocnemis expansa, LH, FSH, progesterone, testosterone, 17 $\beta$-estradiol, corticosterone, prolactin, seasonality, reproduction.

\section{Gonadotrofinas, prolactina, corticosterona, e as hormonas sexuais durante 15 meses de Tartarugas da Amazônia - Podocnemis expansa (Schweigger, 1812) (Testudines: Podocnemididae), em condições de cativeiro}

\begin{abstract}
Resumo
Com o objetivo de obter reprodução em cativeiro de Podocnemis expansa, é necessário reunir o conhecimento a respeito de sua endocrinologia reprodutiva. $\mathrm{O}$ objetivo deste trabalho foi avaliar e caracterizar as concentrações plasmáticas de hormônios gonadotróficos, gonadais, corticosterona e prolactina em Tartarugas da Amazônia em condições de cativeiro. Amostras de sangue foram coletadas durante 15 meses. As amostras foram ensaiadas pelo uso de um radioimunoensáio, prolactina, corticosterona, LH, FSH, testosterona, $17 \beta$-estradiol e progesterona. Verificou-se aumento de padrão sazonal significativo nos níveis de $17 \beta$-estradiol e diminuição dos níveis de progesterona ao longo do ano, o que indica o recrutamento folicular. Isto está relacionado com ciclos ovarianos normais e possivelmente para a integridade funcional do eixo hipotálamo-hipófise-gônadas de fêmeas em cativeiro. Houve correlação negativa entre testosterona e corticosterona nas amostras do sexo masculino, sugestivos de efeito do estresse de manejo sobre o sistema reprodutivo. As concentrações plasmáticas de hormônios gonadotrofinas, gonadais, prolactina e hormônios corticosterona pode ser usado como referência para futuras pesquisas e possíveis abordagens terapêuticas. Os dados médios coletados durante a pesquisa são inéditos para a espécie e pode servir como referência para futuras pesquisas
\end{abstract}


sobre o sistema reprodutivo da tartaruga, também permitindo manejo reprodutivo em cativeiro. Informações sobre esses hormônios devem ser recolhidas a partir de natureza selvagem em diferentes períodos do ano para melhor esclarecimento da fisiologia da reprodução desta espécie.

Palavras-chave: Podocnemis expansa, LH, FSH, progesterona, testosterona, 17 $\beta$-estradiol, corticosterona, prolactina, sazonalidade, reprodução.

\section{Introduction}

The Giant Amazon River Turtle (Podocnemis expansa, Schweigger, 1812b) South America's largest freshwater turtle, has considerable data published concerning clutch size, hatching and nesting behavior and ecology (Vanzolini, 2003; Ferreira Junior and Castro, 2010). Recently, there has been a great interest in the commercialization of Podocnemis expansa, to alleviate the over collection of wild caught turtles. For this purpose, the research on size at sexual maturity is important once it is considered a potential tool through the study of chronology by carcass morphology; besides, it could answer questions regarding longevity, sexual maturity and population age structure (Chinsamy and Valenzuela, 2008).

Research characterizing the gonadic and hormonal variation levels related to reproduction, throughout one or more cycles, would help in the study of the reproductive process and could give feedback on the optimization of captive breeding. The pattern observed could be altered in favor of the captive environment (management stress). It is as necessary to clarify aspects of the reproductive life in nature and captivity, generating results that favor the reproductive management of the species in controlled environments as well as in nature.

The most studied reproductive pattern of the Giant Amazon River turtle is the process of nesting (Alho and Padua, 1982; Gomes and Ferreira Junior, 2011; Alves-Junior et al., 2012).

No research on plasma concentration of different gonadotrophic and reproductive hormones have been reported for Giant Amazon River turtles. In this study, we aimed to better understand the reproductive cycle of Giant Amazon River turtles in captivity and observe the integrity of the hypothalamic--pituitary--gonadal axis. To do so, we measured and monitored hormones in both sexes (LH, FSH, 17ß-estradiol, progesterone, testosterone and corticosterone), during a 15-month period. Knowing the reproductive physiology and endocrinology is necessary to manage reproduction of Podocnemis expansa in captivity.

\section{Material and Methods}

This research consisted of a retrospective formal review by the IACUC-UFG $\left(n^{\circ} 041 / 13\right)$, and was conducted in the Experimental Pisciculture Sector of Universidade Federal of Goiás, Goiania City, Goiás State, located at $16^{\circ} 40^{\prime} 22^{\prime \prime}$ latitude south and $49^{\circ} 15^{\prime} 29^{\prime \prime}$ longitude west, presenting an average height of $730 \mathrm{~m}$. The region's climate is of the B2WB' $4 a$ ' type. In this location, mean temperature reach $21.9^{\circ} \mathrm{C}$ (maximum $29.4{ }^{\circ} \mathrm{C}$ minimum $15.2^{\circ} \mathrm{C}$ ), relative humidity $71.5 \%$, annual precipitation $1487.2 \mathrm{~mm}$ and total insulation $2645.7 \mathrm{~h}$. A total of 45 turtles ( 22 males and 23 females) were transferred from the Brazilian Institute of Environment and Renewable Natural Resources (IBAMA) base, located in Neropolis. The procedures and management of animals were reviewed and approved by IBAMA.

The animals were kept in reservoirs of 30, 10 and 1.5 meters of length, width and height, respectively. The reservoirs were enclosed with a $16 \mathrm{~mm}$ steel fence, 1.30 meters tall and 1 meter away from the river margin. A $10 \mathrm{~m}^{3}, 5$ meters wide, sandbank was built to be used by the animals to sunbathe. The animals were fed with commercial rations for fish ${ }^{1}(9 \mathrm{~mm})$ twice a day during the hottest periods of the day, with guaranteed humidity (max) $8 \%$, crude protein (min) $28 \%$, ether extract (min) $5 \%$, fibrous matter $(\max ) 7 \%$, mineral matter $(\max )$ $10 \%$, calcium $(\max ) 1.2 \%$, and phosphorous $(\min ) 0.6 \%$. The quantity was regulated by animal consumption, and it was reduced during cloudy days.

The turtles used in this experiment had the carapace size as measured by Bataus (1998). These strands refer to wild animals that present a reproductive behavior of aggregation considered able to reproduce. We determined two carapace length groups of females (Group 1-51.51 $\pm 6.37 \mathrm{~cm} ; \mathrm{N}=16$; and Group $2-63.26 \pm 4.66 \mathrm{~cm} ; \mathrm{N}=7$, and three groups of males (Group 1 - 40.27 $\pm 1.13 \mathrm{~cm} ; \mathrm{N}=7$; Group 2 $-44.96 \pm 1.72 \mathrm{~cm}$; $\mathrm{N}=6$; Group $3-53.33 \pm 9.23 \mathrm{~cm} ; \mathrm{N}=9$. During the experimental period the water levels of the reservoirs were kept at the maximum. The water quantity was reduced only during blood collection, in order to note the production and secretion patterns without interference of water decline.

Blood samples were collected by veterinarians in the following periods during 15 months: July, August, September, October, November and February, March, May, June, July and September sequentially. The blood was collected from the occipital sinus or the vertebral sinus and the tail, through vein puncture with the use of $5 \mathrm{~mL}$ syringes with $14 \mathrm{G}$ needles. The blood was centrifuged, packed in $2 \mathrm{~mL}$ Eppendorf tubes and stored in a freezer at $20^{\circ} \mathrm{C}$ until defrosting.

Hormonal analysis was carried out through radioimmunoassay (RIA) (Yalow and Berson, 1960). All of the samples from each experiment were assayed using the same RIA to avoid inter-assay variation. Plasma concentrations of luteinizing hormone (LH), follicle-stimulating hormone (FSH), prolactin (PRL) and corticosterone (CT) were measured for both sexes; $17-\beta$ estradiol $\left(\mathrm{E}_{2}\right)$ and progesterone $\left(\mathrm{P}_{4}\right)$ for females; testosterone $(\mathrm{T})$ for males. The validation for each assay

${ }^{1}$ Guabi Pirá 28 Tipo: extrusada 
was determined using unknow samples in different volumes to evaluate the paralelism with standard curves and the intra-assay coefficients of variation were calculated (Grotjan and Keel, 1996). Plasma concentrations of LH, FSH and PRL were determined by double-antibody RIA using peptide for iodination ( $\mathrm{rLH}-\mathrm{I}_{9}, \mathrm{rFSH}_{-} \mathrm{I}_{7}$ and $\mathrm{rPRL}-\mathrm{I}_{6}$ ), standard reference ( $\mathrm{rLH}-\mathrm{RP}_{3}, \mathrm{rFSH}^{-\mathrm{RP}_{2}}$ and $\mathrm{rPRL}-\mathrm{RP}_{3}$ ), and specific antibodies ( $\mathrm{rLH}^{-\mathrm{S}_{10}}, \mathrm{rFSH}_{11}$ and $\mathrm{rPRL}-\mathrm{S}_{9}$ ) provided by the National Hormone and Peptide Program (NIDDK, Baltimore,MD-USA / Harbor-UCLA Medical Center, CA-USA). Dr. Franci's Laboratory produced the iodinated hormones by chloramine-T method (Hunter and Greenwood, 1962) and the secondary antibody in sheep. The intra-assay coefficients of variation for LH, FSH and PRL were $3 \%, 3 \%$ and $5.8 \%$, respectively. The lower limits of detection were $0.05 \mathrm{ng} / \mathrm{ml}$ for $\mathrm{LH}, 0.2 \mathrm{ng} / \mathrm{ml}$ for FSH and $0.09 \mathrm{ng} / \mathrm{ml}$ for PRL. Plasma CT measure required previous extraction in ethanol. The RIA used specific antibody and standard from Sigma (St. Louis, MO-USA) and $\mathrm{H}_{3}$-corticosterone from NEN Life Sciences Products (Boston, M- USA). The lower limit of detection and the intra-assay coefficient for CT were $1.0 \mathrm{ng} / \mathrm{ml}$ and $2.5 \%$, respectively. Plasma concentrations of $17-\beta$ estradiol, progesterone and testosterone were determined by double antibody radioimmunoassay using specific kits provided by Maia (BioChem ImmunoSystems, Itália S.P.A). The intra-assay coefficients of variation for $17-\beta$ estradiol, progesterone and testosterone were $2.5 \%, 3.2 \%$ and $5.4 \%$, respectively. The lower limits of detection were $1.2 \mathrm{pg} / \mathrm{ml}$ for $17-\beta$ estradiol, $0.3 \mathrm{ng} / \mathrm{ml}$ for progesterone, and $0.3 \mathrm{ng} / \mathrm{ml}$ for testosterone. The data were analyzed by SAS Institute (1997). Descriptive analyses were presented to the hormone levels (means, deviation standards and range). The hormonal levels data were transformed to logarithm scale in order to analyze it by the Fisher correlations, variance analyses utilizing Duncan test, and relationship between months and plasma levels of 17- $\beta$ estradiol, progesterone in females.

\section{Results and Discussion}

The carapace size groups did not show hormone level differences, therefore we compare sex groups.

Table 1 presents the plasma levels of $17 \beta$-estradiol, evaluated during 15 months. We observed an increase in $17 \beta$-estradiol concentrations during the period between July and May, which is the rainy season. We verified a decrease in the plasma levels of the $17 \beta$-estradiol of the following year and a subsequent increase in September. This pattern is likely to represent a seasonal behavior, even though these animals were in captivity. As for progesterone plasma levels (Table 1), we observed a seasonal pattern, increased during the months of the dry season (July to October), whereas it decreased during the rainy season (November to May). The period between August and September is the nesting season in the Araguaia River region.

Analysis of the relation between logarithm values of $17 \beta$-estradiol and progesterone plasma concentrations through time can be represented by the following cubic equations, respectively: $\mathrm{LgEstr}=0.848+1.379 * \mathrm{X}-0.257 * \mathrm{X}^{2}+0.015 * \mathrm{X}^{3}$, $\mathrm{R}^{2}=0.30, \mathrm{P}<0.001$ and $\mathrm{LgPorg}=6.09+0.455^{*} \mathrm{X}-$ $1.60 * X^{2}+0.011 * X^{3}, R^{2} 0.35 P<0.001$ (Figure 1). We verified that the plasma levels of $17 \beta$-estradiol and progesterone showed an inverse relationship. This cycle was observed throughout the year and coincides with the nesting in the wild, which occurs during the dry season (Bataus, 1998). The occurrence of the nesting season when the river flow is the lowest is the only reproduction pattern known for this species. Therefore, the nesting season may vary from place to place, and according to the occurrence of the dry season. Some of the nesting seasons in different locations in South America are December-January (in Rio Branco, Roraima State, Brazil), February to March (Orinoco River, Venezuela), August to September (Pacaya River, Peru, Madeira and Jaruá, Brazil), October (Trombetas River, Pará State, Brazil), and July to August (Araguaia River, Goiás and Tocatins States, Brazil) (Alho and Pádua, 1982).

Previous studies in temperate zone species revealed that progesterone is the main steroid hormone produced by chelonians (Klicka and Mahmoud, 1972, 1973; Chan and Callard, 1974; Callard et al.1978), although its physiological role in chelonian species is still not understood. In ovoviviparous reptiles, progesterone acts as an antigonodal agent by inhibiting ovary growth during gestation. It is possible that, in oviparous turtles, this antigonadal action allows the egg to remain in the reproductive trait until the environment presents favorable conditions for oviposition. In other turtle species, high levels of progesterone usually indicate the presence of the corpus luteum and are related to the ovulation and nesting periods (Callard et al., 1978; Lewis et al., 1979; Sarkar et al., 1996; Mahmoud and Licht, 1997). The antigonadotropic action of progesterone in turtles may inhibit endogenous gonadotrophins and may have an important role in retaining the egg and inhibiting vitellogenesis (Ho et al., 1982; Callard et al., 1991). In this study, we did not observe an inhibiting pattern of progesterone by the gonadotrophins, perhaps because we collected only one sample per month and therefore could not detect this trend. The luteolysis with an increase of $17 \beta$-estradiol could be suggestive of a starter of the vitellogenesis process in Giant Amazonian river turtles.

The high plasma levels of $17 \beta$-estradiol verified during the pre-vitellogenic phase is directly related to follicle size; therefore, estradiol production co-relates with follicular growth (Lance and Callard, 1978). Plasma detection of either $17 \beta$-estradiol or progesterone is considered to be a good indication of a functional reproductive system. For instance, in Trachemys scripta, the pre-ovulatory phase is characterized by a short period during which the plasma levels of both estrogen and progesterone are high, only to rapidly drop after ovulation. Some short peaks of estrogen production also occur due to the production of small follicles in the ovary (Callard et al., 1978). It is possible that animals in captivity have a longer pre-vitellogenic phase, if compared to those in wildlife.

We assessed the plasma concentrations of testosterone in males during the completely experimental period (Table 2) 


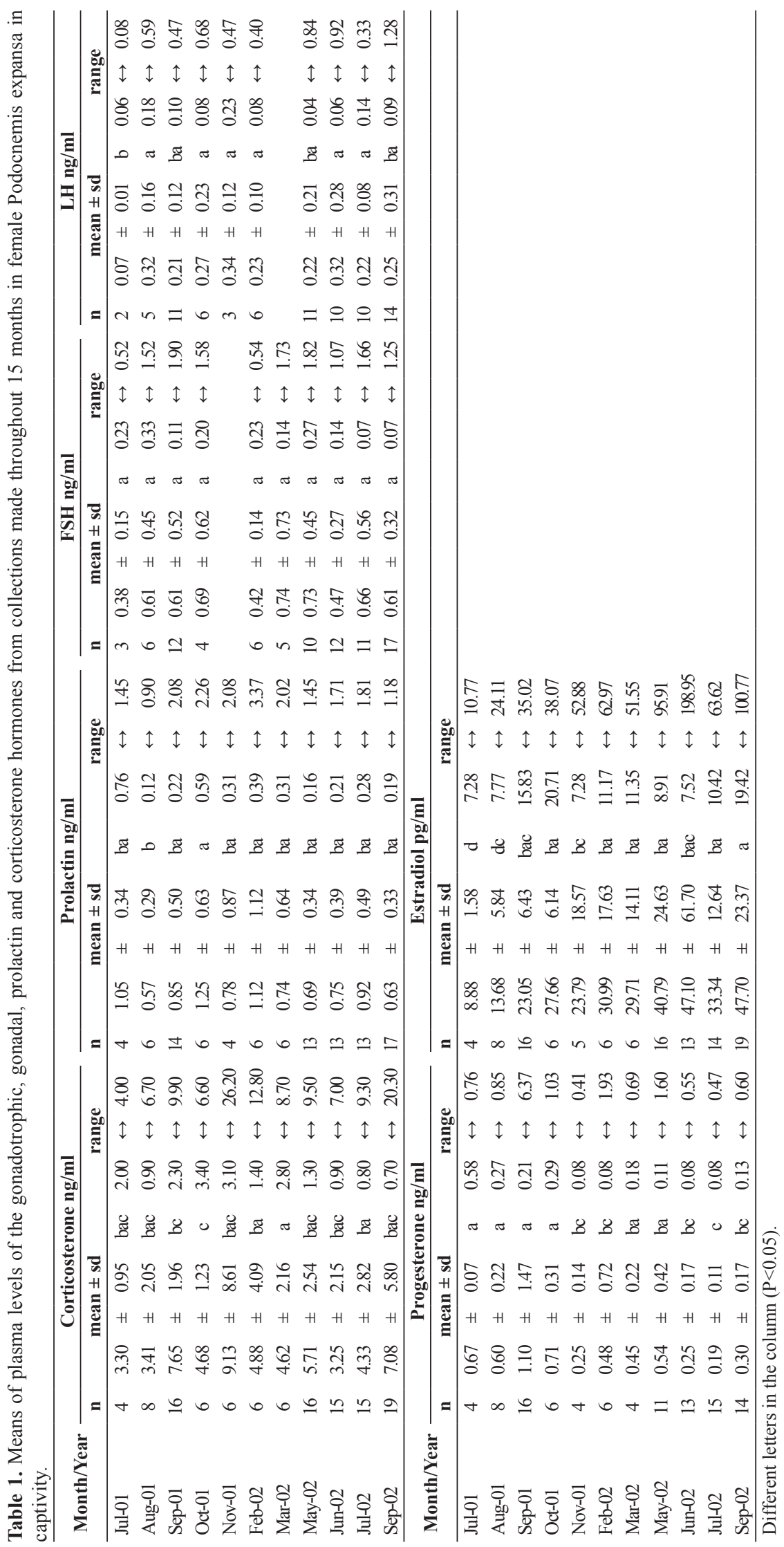



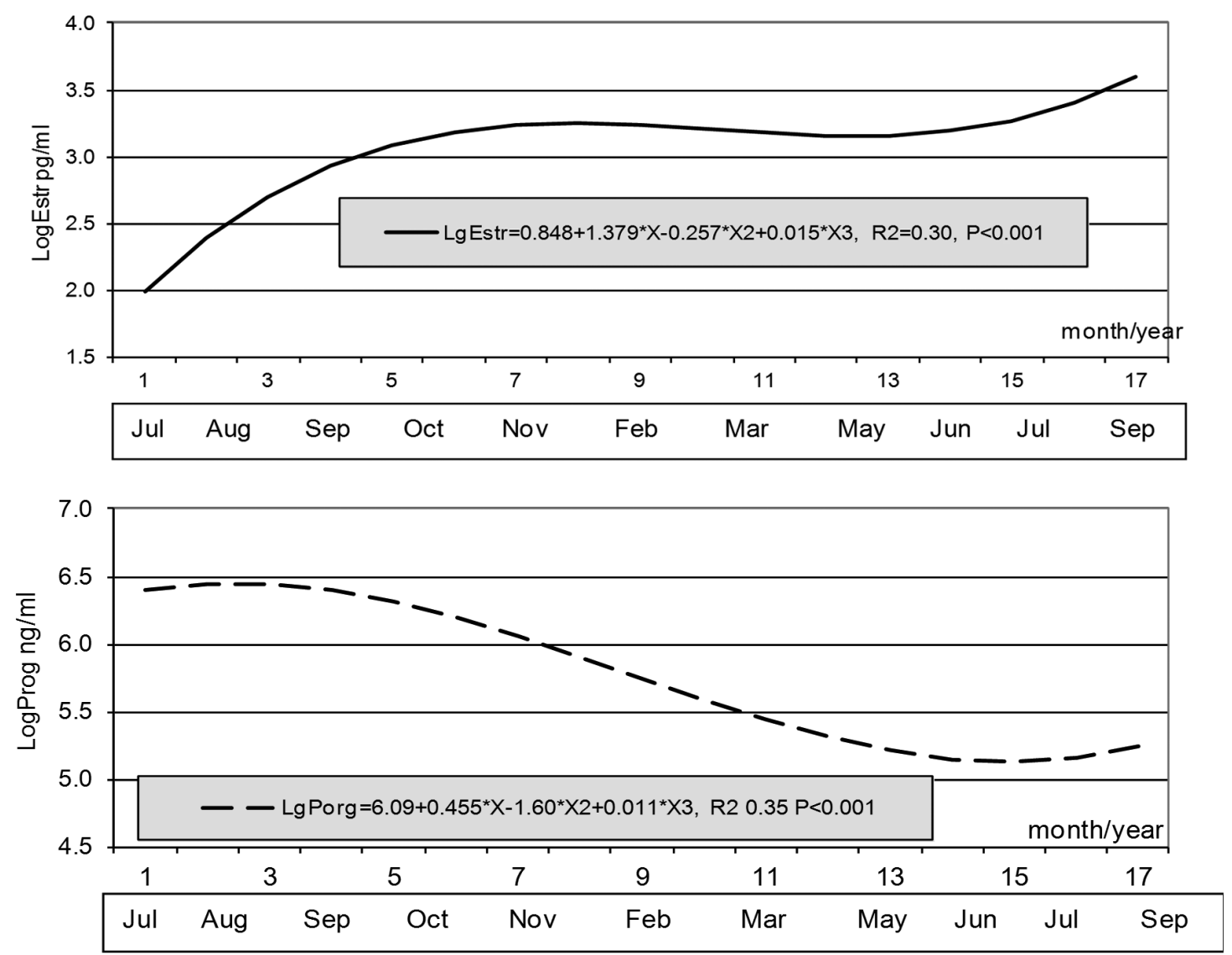

Figure 1. Relation between time and logarithm values of plasma levels of progesterone and 17- $\beta$-estradiol in female Giant Amazonian river turtles (Podocnemis expansa) in captivity during 15 months.

and verified a rise in May and July of the second year. This fact was not observed during the year before, thus could not be considered a seasonal pattern.

A clearly defined seasonal pattern in reptiles is well known (Callard et al., 1978) and our findings indicate a seasonal pattern for hormone production in females of Podocnemis expansa in captivity. For instance, in male reptiles, as in mammals, testosterone levels present a cyclic pattern that works according to the occurrence of peaks of hormone releases of GnRH and LH throughout the day (Callard et al., 1976; Lance et al., 1977; Amann and Schanbacher, 1983). Therefore, we expected that a similar pattern could be found in the males living under the same conditions. Analysis of the variation of the average plasma concentrations of testosterone in males through time showed two peaks, one in May and another in July. (Table 2); however, the same testosterone peak was not seen in July in the previous year. Additionally, our study did not start until that month; therefore, we have no information about the testosterone levels in the months prior to July 2001. These turtles had been transferred to the experimental site from an IBAMA station located $25 \mathrm{Km}$ away, in March 2001. Therefore, our data were collected when these animals had just arrived in the new environment.
Thus, it is possible that this lack of testosterone peaks in 2001 reflects some of the changes that the animals may have been submitted to when transferred to the new tank (water conditions, nutrition, population density, transport, and other stress-related factors)

The analysis of plasma concentrations of corticosterone (Tables 1 and 2 females and males respectively) showed a weak negative correlation $(-0.20, \mathrm{P}<0.05)$, between the levels of testosterone. Previous studies done in several species showed that corticosterone inhibits the production of sexual hormones under stress conditions (Lance and Lauren, 1984; Gregory et al, 1996; Cash et al., 1997).

However, we cannot rule out that the small number of animals used in this research, and our monthly sample collection may have contributed to not detecting the seasonal hormone production during the first year (2001). We observed additional correlations for other hormones in males, such as a positive correlation between prolactin and FSH. In females, we verified a positive, although weak, correlation between corticosteroid and progesterone, whereas we noticed an inverse correlation between both LH $(r=-0.20, P<0.10)$ and $17 \beta$-estradiol $(r=-19, \mathrm{P}<0.07)$ with progesterone. 


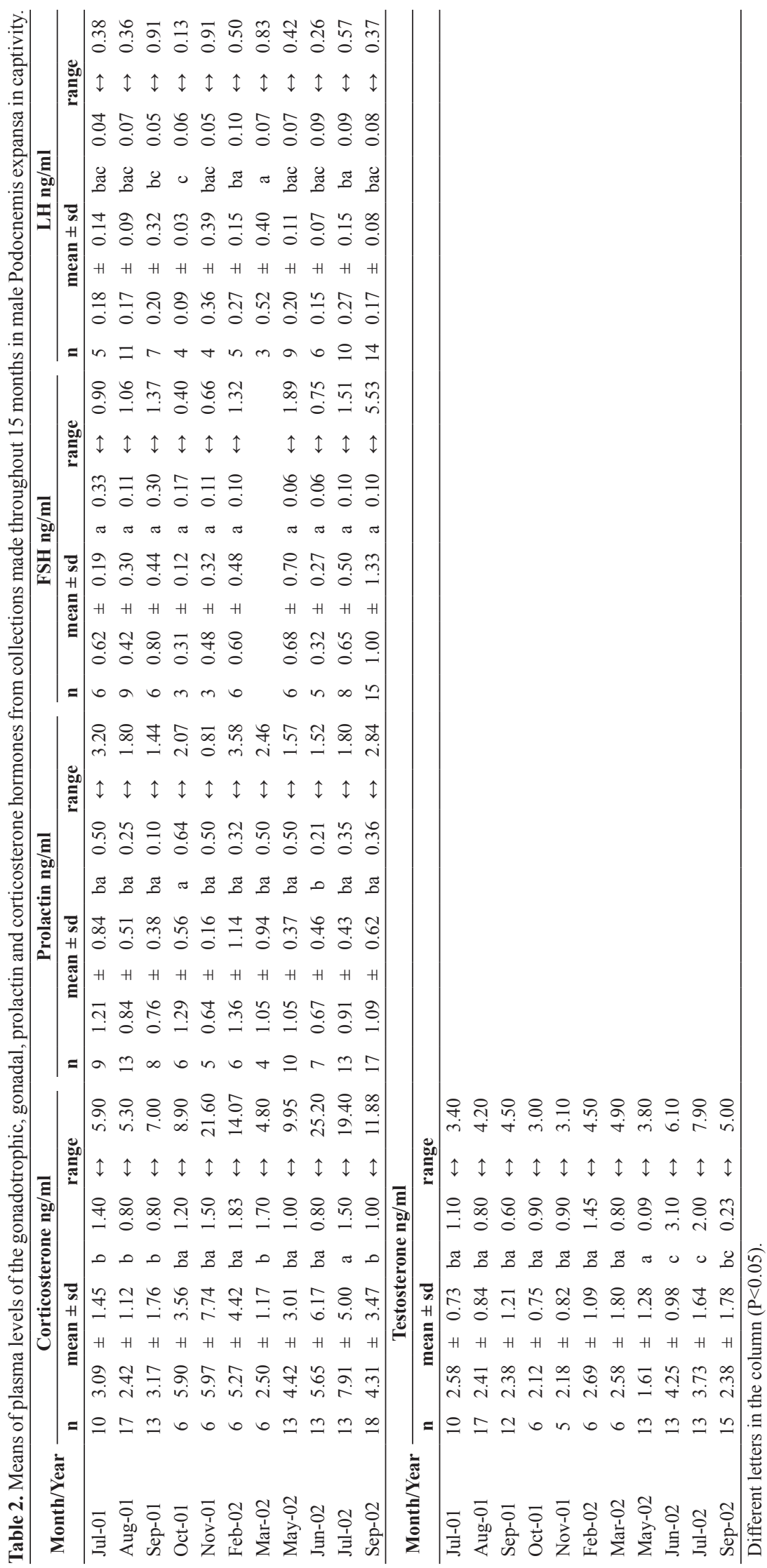


It is known that corticosterone levels increase when animals, including reptiles, are manipulated or kept in captivity, reason why this hormone is considered as a stress indicator (Lance and Lauren, 1984; Gregory et al., 1996; Cash et al., 1997). On the other hand, it has been shown in two turtle species (Chelydra serpentina and Chrysemys picta) that a decrease in testosterone levels occurs when these animals are taken to captivity (Licht et al., 1985; Mendonça and Licht, 1986; Mahmoud et al., 1989). This inverse relationship between corticosterone and testoterone levels was also verified in our study $(\mathrm{r}=0.20, \mathrm{P}<0.03)$.

Variance analysis of the logarithmic transformation of hormone concentrations in males showed that testosterone concentrations varied significantly throughout the months (lgTest $\mathrm{SQM}=1.99, \mathrm{~F}=3.88, \mathrm{P}<0.0002, \mathrm{Rq}=0.27, \mathrm{CV}=9.35$ ), whereas in females we observed differences in hormone concentrations for $17 \beta$-estradiol (lgestr $\mathrm{SMQ}=1.61, \mathrm{~F}=4.26$, $\mathrm{P}<0.0001, \mathrm{Rq}=0.29, \mathrm{CV}=18.8)$, progesterone (lgprog $\mathrm{SQM}=3.11, \mathrm{~F}=7.05, \mathrm{P}<0.0001, \mathrm{Rq}=0.44, \mathrm{CV}=11.39)$, and corticosterone (lgcort $\mathrm{SMQ}=1.31, \mathrm{~F}=2.59, \mathrm{P}<0.007$, $\mathrm{Rq}=0.20, \mathrm{CV}=8.52$ ).

Despite the fact that the turtles were kept in captivity, and possibly under stress conditions, we detected the production of FSH, both in females (Table 1) and in males (Table 2), throughout the months (July 2001 to September 2002). Contrary from what we expected, no relationship could be established between FSH and any other hormone in both sexes, and no significant production could be detected at any time. However, a weak positive correlation could be detected between FSH and prolactin $(\mathrm{r}=0.24, \mathrm{P}<0.05)$ in males. Interestingly, a debate exists about the role of prolactin production in males, and some authors suggest that the hormone may be involved with spermatogenesis in mammals (Lincoln et al., 2001).

We observed a similar situation for LH in both sexes, which, like $\mathrm{FSH}$, is another hormone produced by the pituitary (Tables 1 and 2, female and males, respectively), and it is also under control of the hypothalamic GnRH (Lance and Callard, 1978). These findings indicate that the animals, although living in captivity, seem to have a functional pituitary.
No relationship could be established between prolactin secretion and progesterone levels in females, or between prolactin and any other hormone in males, except for FSH $(\mathrm{r}=0.24, \mathrm{P}<0.05)$. No significant differences in prolactin production were observed in any sex, throughout the months. The lack of relation between prolactin and progesterone plasma levels in females was unexpected, as prolactin is a hormone known for its anti-gonadal activity in reptiles (Callard and Zeigler Junior, 1970). Additionally, early studies done in turtles showed that progesterone induces prolactin production (Callard et al., 1975).

Tables 1 and 2 show plasma concentrations of prolactin through time in females and males, respectively. The lack of information about the mating behavior of Podocnemis expansa in captivity makes estimating what would be the standard hormonal patterns very difficult, especially in males.

Table 3 presents the means of plasma concentration levels of the hormones studied during the 15 months in both sexes of the Podocnemis expansa species. Tables 2 and 3 show the values of these hormones for females and males, respectively, for each of the months of collection. These data can be considered the first report for this species.

Reproduction is controlled by a complex and delicate endocrine mechanism and it may be affected by biological patterns related to the environment and reproductive strategies of each species. The biological patterns may be incompatible with the current captivity centers, or they may even not be related to the reproductive strategies or the alternation of production rates and hormonal releases during the reproductive process. The impact caused by stress over reproduction could be a great factor regarding the possible failures in captivity breeding.

Knowing the reproductive physiology and endocrinology of Podocnemis expansa may help manage reproduction in captivity. Because the factors related to reproduction in captivity are not sufficiently clear, this research aimed at collecting data that will allow further comprehension of the reproductive physiology of this species, thus allowing better management in captivity.

Table 3. Means of plasma levels of the gonadotrophic, gonadal, prolactin and corticosterone hormones over 15 months in males and females of Podocnemis expansa in captivity.

\begin{tabular}{llccccccc}
\hline Gender & & Hormones & n & mean & \pm & sd & \multicolumn{3}{c}{ range } \\
\hline \multirow{4}{*}{ Females } & 17b estradiol pg/ml & 113 & 33.63 & \pm & 27.85 & 7.28 & $\leftrightarrow$ & 198.95 \\
& Progesterone ng/ml & 101 & 0.51 & \pm & 0.69 & 0.08 & $\leftrightarrow$ & 6.37 \\
& Prolactin $\mathrm{ng} / \mathrm{ml}$ & 102 & 0.81 & \pm & 0.52 & 0.12 & $\leftrightarrow$ & 3.37 \\
& LH ng/ml & 79 & 0.25 & \pm & 0.21 & 0.04 & $\leftrightarrow$ & 1.28 \\
& FSH ng/ml & 87 & 0.60 & \pm & 0.43 & 0.07 & $\leftrightarrow$ & 1.90 \\
& Cortiscoterone ng/ml & 117 & 5.49 & \pm & 3.96 & 0.70 & $\leftrightarrow$ & 26.20 \\
\hline \multirow{3}{*}{ Males } & Testosterone ng/ml & 116 & 2.68 & \pm & 1.43 & 0.09 & $\leftrightarrow$ & 7.90 \\
& Prolactin ng/ml & 98 & 0.99 & \pm & 0.61 & 0.10 & $\leftrightarrow$ & 3.58 \\
& LH ng/ml & 78 & 0.21 & \pm & 0.18 & 0.04 & $\leftrightarrow$ & 0.91 \\
& FSH ng/ml & 68 & 0.66 & \pm & 0.73 & 0.06 & $\leftrightarrow$ & 5.53 \\
& Cortiscoterone ng/ml & 121 & 4.48 & \pm & 4.03 & 0.80 & $\leftrightarrow$ & 25.20 \\
\hline
\end{tabular}


Our study suggests a seasonal pattern for the levels of $17 \beta$-estradiol and the occurrence of a decrease in the levels of progesterone, which indicates follicular recruitment.

In this study we measured the plasma levels of a number of hormones in males and females of Podocnemis expansa in captivity. Our purpose was to better understand the physiology of Podocnemis expansa, due to the lack of reference values available for all the hormones we measured (LH, FSH, progesterone 17 $\beta$-estradiol, testosterone, prolactin and corticosterone). We present for the first time mean values for these hormones, which can be used and compared for future studies as well as for therapeutic purposes regarding assisted reproduction.

Measurements of these hormones in nature, and in different moments throughout the year, combined with investigations of the hypothalamic-pituitary-gonadal axis of animals in captivity, are necessary to shed light on the reproductive physiology of the Giant Amazon river turtle.

\section{Acknowledgements}

This research consisted of a retrospective formal review by the IACUC-UFG $\left(n^{\circ} 041 / 13\right)$. The authors are grateful to Yeda Bataus from Centro Nacional de Pesquisa e Conservação de Répteis e Anfíbios (RAN) of the Brazilian Institute of Environment and Renewable Natural Resources (IBAMA) for allowing the use of animals and data.

\section{References}

ALHO, C.J.R. and PÁDUA, L.F.M., 1982. Sincronia entre o regime de vazante do rio e o comportamento de nidificação da Tartaruga da Amazônia, Podocnemis expansa, (Testudinata: Pelomedusidae). Acta Amazonica, vol. 12, no. 2, pp. 323-326.

ALVES-JÚNIOR, J.R.F., LUSTOSA, A.P.G., BOSSO, A.C.S., BALESTRA, R.A.M., BASTOS, L.F., MIRANDA, L.B. and SANTOS, A.L.Q., 2012. Reproductive indices in natural nests of giant Amazon river turtles Podocnemis expansa (Schweigger, 1812) (Testudines, Podocnemididae) in the Environmental Protection Area Meanders of the Araguaia river. Brazilian Journal of Biology $=$ Revista Brasileira de Biologia, vol. 72, no. 1, pp. 199-203. http://dx.doi.org/10.1590/S1519-69842012000100024. PMid:22437402.

AMANN, R.P. and SCHANBACHER, B.D., 1983. Physiology of male reproduction. Journal of Animal Science, vol. 57, no. 2, suppl. 2, pp. 380-403. PMid:6352590.

BATAUS, Y.S.L., 1998. Estimativa de parâmetros populacionais de Podocnemis expansa (Tartaruga-da-Amazônia no rio Crixásaçu (GO) a partir de dados biométricos. Goiânia: Universidade Federal de Goiás. Dissertação de Mestrado em Biologia.

CALLARD, I.P. and ZEIGLER JUNIOR, H., 1970. Inhibitory effects of prolactin upon gonadotrophin-stimulated ovarian growth in the iguanid lizard, Dipsosaurus dorsalis. The Journal of Endocrinology, vol. 47, no. 1, pp. 131-132. http://dx.doi. org/10.1677/joe.0.0470131. PMid:5428910.

CALLARD, I.P., CALLARD, G.V., LANCE, V. and ECCLES, S., 1976. Seasonal changes in testicular structure and function and the effects of gonadotropins in the freshwater turtle, Chrysemys picta. General and Comparative Endocrinology, vol. 30, no. 3, pp. 47-56. http://dx.doi.org/10.1016/0016-6480(76)90086-1. PMid:992355.

CALLARD, I.P., ETHERIDGE, K., GIANNOUKOS, G., LAMB, T. and PEREZ, L., 1991. The role of steroids in reproduction in female elasmobranchs and reptiles. The Journal of Steroid Biochemistry and Molecular Biology, vol. 40, no. 4-6, pp. 571-575. http://dx.doi.org/10.1016/0960-0760(91)90278-D. PMid:1958559.

CALLARD, I.P., LANCE, V., SALHANICK, A.R. and BARAD, D., 1978. The annual ovarian cycle of Chrysemys picta: Correlated changes in plasma steroids and parameters of vitellogenesis. General and Comparative Endocrinology, vol. 35, no. 3, pp. 245-257. http://dx.doi.org/10.1016/0016-6480(78)90069-2. PMid:689359.

CALLARD, I.P., MCCHESNEY, I. and SCANES, C., 1975. Proceedings: Influence of mammalian and avian gonadotrophins and prolactin on steroidogenesis in turtle (Chrysemys picta) follicular and luteal tissues. The Journal of Endocrinology, vol. 65, no. 3, pp. 22P. PMid:1151223.

CASH, W.B., HOLBERTON, R.L. and KNIGHT, S.S., 1997. Corticosterone secretion in response to capture and handling in free-living red-eared slider turtles. General and Comparative Endocrinology, vol. 108, no. 3, pp. 427-433. http://dx.doi. org/10.1006/gcen.1997.6999. PMid:9405119.

CHAN, S.W. and CALLARD, I.P., 1974. Reptilian ovarian steroidogenesis and the influence of mammalian gonadotrophins (follicle-stimulating hormone and luteinizing hormone) in vitro. The Journal of Endocrinology, vol. 62, no. 2, pp. 267-275. http:// dx.doi.org/10.1677/joe.0.0620267. PMid:4415575.

CHINSAMY, A. and VALENZUELA, N., 2008. Skeletochronology of the endangered side-neck turtle, Podocnemis expansa. South African Journal of Science, vol. 104, pp. 311-314.

FERREIRA JUNIOR, P.D. and CASTRO, P.T.A., 2010. Nesting ecology of Podocnemis expansa (Schweigger, 1812) and Podocnemis unifilis (Troschel, 1848) (Testudines, Podocnemididae) in the Javaés River, Brazil. Brazilian Journal of Biology $=$ Revista Brasileira de Biologia, vol. 70, no. 1, pp. 85-94. http://dx.doi.org/10.1590/ S1519-69842010000100012. PMid:20231963.

GOMES, A.S. and FERREIRA JUNIOR, P.D., 2011. Management and relocation of nests of Podocnemis expansa (Schweigger, 1812) (Testudines, Podocnemididae) on the Crixás-Açu River, Brazil. Brazilian Journal of Biology = Revista Brasileira de Biologia, vol. 71, no. 4, pp. 975-982. http://dx.doi.org/10.1590/ S1519-69842011000500017.

GREGORY, L.F., GROSS, T.S., BOLTEN, A.B., BJORNDAL, K.A. and GUILLETTE JUNIOR, L.J., 1996. Plasma corticosterone concentrations associated with acute captivity stress in wild loggerhead sea turtles (Caretta caretta). General and Comparative Endocrinology, vol. 104, no. 3, pp. 312-320. http://dx.doi. org/10.1006/gcen.1996.0176. PMid:8954764.

GROTJAN, H.E. and KEEL, B.A., 1996. Data interpretation and quality control. In: E.P. DIAMANDIS and T. K. CHRISTOPOULOS, eds. Immunoassay. San Diego: Academic Press, pp. 51-93.

HO, S.M., KLEIS, S., MCPHERSON, R., HEISERMANN, G.L. and CALLARD, I.P., 1982. Regulation of vitellogenesis in reptiles. Herpetologica, vol. 38, no. 1, pp. 40-50.

HUNTER, W.M. and GREENWOOD, P.C., 1962. Preparation of 1-131 labeled growth hormone of high specific activity. Nature, vol. 194, no. 4827, pp. 495-496. http://dx.doi.org/10.1038/194495a0. PMid:14450081. 
KLICKA, J. and MAHMOUD, I.Y., 1972. Conversion of pregnenolone-4 $14 \mathrm{c}$ to progesterone- $414 \mathrm{c}$ by turtle corpus luteum. General and Comparative Endocrinology, vol. 19, no. 2, pp. 367-369. http://dx.doi.org/10.1016/0016-6480(72)90120-7. PMid:4635469.

KLICKA, J. and MAHMOUD, I.Y., 1973. Conversion of cholesterol to progesterone by turtle corpus luteum. Steroids, vol. 21, no. 4, pp. 483-496. http://dx.doi.org/10.1016/0039-128X(73)90039-1. PMid:4735481.

LANCE, V. and CALLARD, I.P., 1978. In vivo responses of female snakes (Natrix fasciata) and female turtles (Chrysemys picta) to ovine gonadotropins (FSH and LH) as measured by plasma progesterone, testosterone, and estradiol levels. General and Comparative Endocrinology, vol. 35, no. 3, pp. 295-301. http://dx.doi.org/10.1016/0016-6480(78)90075-8. PMid:689361.

LANCE, V. and LAUREN, D., 1984. Circadian variation in plasma corticosterone in the American alligator, Alligator mississippiensis, and the effects of ACTH injections. General and Comparative Endocrinology, vol. 54, no. 1, pp. 1-7. http:// dx.doi.org/10.1016/0016-6480(84)90192-8. PMid:6327457.

LANCE, V., SCANES, C. and CALLARD, I.P., 1977. Plasma testosterone levels in male turtles, Chrysemys picta, following single injections of mammalian, avian and teleostean gonadotropins. General and Comparative Endocrinology, vol. 31, no. 4, pp. 435-441. http://dx.doi.org/10.1016/0016-6480(77)90032-6. PMid:195862.

LEWIS, J., MAHMOUD, I.Y. and KLICKA, J., 1979. Seasonal fluctuations in the plasma concentrations of progesterone and oestradiol-17b in the female snapping turtle (Chelydra serpentina). The Journal of Endocrinology, vol. 80, no. 1, pp. 127-131. http:// dx.doi.org/10.1677/joe.0.0800127. PMid:429947.

LICHT, P., BREITENBACH, G.L. and CONGDON, J.D., 1985. Seasonal cycles in testicular activity, gonadotropin, and thyroxine in the painted turtle, Chrysemys picta, under natural conditions. General and Comparative Endocrinology, vol. 59, no. 1, pp. 130-139. http://dx.doi.org/10.1016/0016-6480(85)90427-7. PMid:3926601.
LINCOLN, G.A., TOWNSEND, J. and JABBOUR, H.N., 2001. Prolactin Actions in the Sheep Testis: A Test of the Priming Hypothesis. Biology of Reproduction, vol. 65, no. 3, pp. 936-943. http://dx.doi.org/10.1095/biolreprod65.3.936. PMid:11514361.

MAHMOUD, I.Y. and LICHT, P., 1997. Seasonal changes in gonadal activity and the effects of stress on reproductive hormones in the common snapping turtle, Chelydra serpentina. General and Comparative Endocrinology, vol. 107, no. 3, pp. 359-372. http:// dx.doi.org/10.1006/gcen.1997.6944. PMid:9268617.

MAHMOUD, I.Y., GUILLETTE, L.J. Jr., MCASEY, M.E. and CADY, C., 1989. Stress-induced changes in serum testosterone, estradiol-17b and progesterone in the turtle, Chelydra serpentina. Comparative Biochemistry and Physiology. A. Comparative Physiology, vol. 93, no. 2, pp. 423-427. http://dx.doi.org/10.1016/03009629(89)90060-1.

MENDONÇA, M.T. and LICHT, P., 1986. Seasonal cycles in gonadal activity and plasma gonadotropin in the musk turtle, Sternotherus odoratus. General and Comparative Endocrinology, vol. 62, no. 3, pp. 459-469. http://dx.doi.org/10.1016/00166480(86)90056-0. PMid:3770437.

SARKAR, S., SARKAR, N.K. and MAITI, B.R., 1996. Seasonal patterns of ovarian growth and interrelated changes in plasma steroid levels, vitellogenesis, and oviductal function in the adult female softshelled turtle Lissemys punctata punctata. Canadian Journal of Zoology, vol. 74, no. 2, pp. 303-311. http://dx.doi. org/10.1139/z96-038.

SAS INSTITUTE, 1997. SAS user's guide: statistics. 6th ed. Cary: SAS Institute Inc. 670 p.

VANZOLINI, P.E., 2003. On clutch size and hatching success of the South American turtles Podocnemis expansa (Schweigger, 1812) and P. unifilis Troschel, 1848 (Testudines, Podocnemididae). Anais da Academia Brasileira de Ciencias, vol. 75, no. 4, pp. 415-430. http://dx.doi.org/10.1590/S0001-37652003000400002. PMid:14605677.

YALOW, R.S. and BERSON, S.A., 1960. Immunoassay of endogenous plasma insulin in man. The Journal of Clinical Investigation, vol. 39, no. 7, pp. 1157-1175. http://dx.doi. org/10.1172/JCI104130. PMid:13846364. 